\title{
Vibrational spectroscopy for the study of Chilean cultural heritage
}

\author{
Marcelo M Vallette Campos $^{*+}$ and Tomás Alvarado Aguayo ${ }^{\dagger}$
}

\begin{abstract}
Background: Natural and synthetic colouring products along with its associated supporting materials have been studied in several expressions of the Chilean cultural heritage using vibrational spectroscopy. These expressions include archaeological remains as well as works of art.

Results: Among the materials studied so far we can count pigments found in archaeological sites from the north of Chile, in plaster (wall paintings) and in polychrome (beams), and dyes mainly related to added components on historic silk textiles. Identification of materials resulted to be relevant to know about Chilean culture through history.

Conclusions: The vibrational knowledge obtained contributes to give solid data as a complement to the different information aspects collected by conservation professionals involved in the characterization and conservation procedures of cultural heritage and also it gives us the opportunity to share knowledge and to give value to objects that not always are of the public domain.
\end{abstract}

\section{Background}

Techniques that involve micro-sampling or non-destructive are important aspects to consider when dealing with cultural heritage and unique objects while pursuing characterization through analyses of ancient samples [1-4]. Raman spectroscopy is a powerful technique for the analysis of different kinds of materials, showing advantages related to the specificity, sensitivity, reproducibility, applicability, mobility and resolution (spatial and spectral) [5]; moreover, it is a non-invasive and non-destructive technique by itself. These advantages, coupled with recent developments in instrumentation and techniques, particularly the surface enhanced Raman spectroscopy (SERS), have made it possible to extend its use in archaeometry and conservation [5-11]. Raman spectroscopy allowed identifying pigments and dyes used in the preparation of manuscripts, paintings, ceramics and textiles [12-17]. Its meaningful disadvantage lies in the formation of fluorescence, which is an accompanying phenomenon in the measurements of diverse materials; the nanostructured metal surfaces in the SERS technique, and the adequate

\footnotetext{
* Correspondence: facien05@uchile.cl

${ }^{\dagger}$ Equal contributors

Department of Chemistry, Faculty of Sciences, University of Chile, Santiago,

Chile
}

use of specific lasers reduce, or totally quench the fluorescence.

Infrared spectroscopy (FTIR) has been widely present in the study of cultural heritage and it has become a permanent part of the instrumental techniques used in routine inspection of objects and materials related to the conservation of cultural objects. It is one of the most appropriate techniques to identify organic compounds presents in most several materials (e. g. binding media, varnishes, adhesives, etc.). It does, however, present some disadvantages (i.e. water absorption) related to the experimental procedures. Classically, a considerable amount of sample was required to disperse in an "IR transparent" material, such as $\mathrm{KBr}$ or $\mathrm{NaCl}$, to form a pellet from where the information was obtained. This resulted, in most cases, in the sacrifice of the sample in order to obtain good quality results. Fortunately, instrumental advances have allowed obtaining the same information with fewer amounts of sample and practically without preparation. One of these advances is the use of attenuated total reflection (ATRFTIR) sampling method, in which a small fragment of the sample is pressed against a crystal used as a medium to make the IR radiation to interact with the material. Despite this, in most of the cases the original form of the sample is modified somehow. FTIR besides being micro-destructive to the object is also destructive to the sample. 
The present work deals with our last results concerning the spectroscopic studies, mainly vibrational Raman and infrared, of different materials in the Chilean cultural heritage. The interest is focused on archaeological samples [18, 19], Diaguita pottery [20], mural painting [12], painted beams [21] and historical silks [22].

\section{Results and discussion}

Studied objects, selected to be presented in this work, represent a wide sample of the materials found in the Chilean cultural heritage. The findings allow us to show the versatility of the vibrational tools used, as well as to help improving the contexts in which the objects are/ were in each case. Also it gives us the opportunity to share knowledge and to give value to objects that not always are of the public domain. The specific insights on each object are presented in the following sections.

\section{Archaeological pigments}

Samples of yellow pigment blocks from the archaeological site Playa Miller 7 (PLM7) of the Formative Period (3700-1500 years B.P.) on the northern coast of Chile were studied using micro-Raman data [see Additional file 1] [18]. Samples from complete blocks, detached fragments or powder were chosen. Yellow blocks (Fig. 1a, b), from the archaeological site consist mainly of a finely ground pigment. In some blocks finely grounded elongated structures (incorporated in the mixture) were identified as algae [23]. The yellow color is not often found in contexts of archaic hunter-gatherer groups. The yellow paint has been observed in the coating of a mummy of the Macarena Chinchorro site 38 and in rock art paintings of Andean foothills without further analyses. A spectral comparison between the archaeological samples and those from Andean geothermal areas of Arica and Parinacota: Jurasi (JU), located at

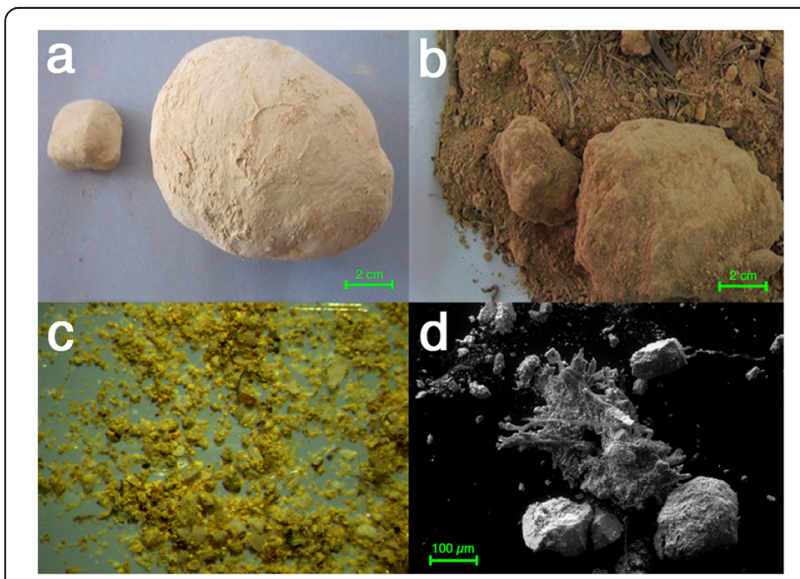

Fig. 1 Pigment samples. Pigment blocks from Playa Miller with (a) and without (b) the presence of algae. Pigment sample from Chorrillos, view under optical microscope (c) and under SEM (d)
$4000 \mathrm{~m}$ above sea level, was carried out. Until now in South America, yellow pigments has received little attention. Moreover yellow pigment such as natrojarosite, has only been reported in the cave paintings of Inca Cave 4 site in the region of Jujuy, Argentina [24], and in other sites in Argentinean Patagonia [25]. Jarosites are a large family of minerals that have a general formula $\mathrm{M}_{\mathrm{n}}\left(\mathrm{Fe}^{3+}\right)_{6}\left(\mathrm{SO}_{4}\right)_{4}(\mathrm{OH})_{12}$, where $\mathrm{M}$ can be $\mathrm{K}^{+},\left(\mathrm{NH}_{4}\right)^{+}$, $\mathrm{Na}^{+}, \mathrm{Ag}^{+}$or $\mathrm{Pb}^{2+}$ and $\mathrm{n}=2$ for monovalent cations and 1 for the divalent cations [26]. The mineralogical characteristics and chemical properties of the jarosites have been widely studied [26-30]. The natrojarosite samples for the Raman study were extracted from the PLM7 Archaeological Sites 14 and 15, and from the Jurasi hydrothermal site 17 and 18. The band assignment was performed on the basis of published data [29, 30] and general spectral data [31]. These results indicate that most of the bands correspond to vibration normal modes associated to jarosite type compounds. The spectral comparison between the archaeological samples and those from the geothermal areas allowed us to infer that this hydrothermal source was probably used as source of yellow pigment by pre-Hispanic inhabitant of the Formative Period. Slight differences in wavenumbers are not enough information allowing differentiating jarosites. However, XRF results, and previous results obtained by SEM-EDX and XRD indicate that the main yellow pigments are natrojarosite and $\mathrm{K}$-jarosite when compared with a database [32]. For the first time, results support the idea that minerals from the jarosite family have been used in Chile in ancient times (3700-1500 years B.P.).

Also, we show results on the analyses performed on an archaeological yellow pigment of an archaeological funerary site in Chorrillos, Calama city, in the north of Chile (Fig. 1c, d). The pigment sample was found in a mollusk shell making part of the grave goods related to a female individual (ca. 25-30 years old) dating to the Early Formative Period (800-200 B.P.). Here, we display and discuss results on the first study pointing to the identification of orpiment [19]. The identification of the toxic yellow arsenic sulfide mineral, orpiment, in archaeological mortuary contexts was performed by using optical microscopy, SEM, EDX, ${ }^{1} \mathrm{H}-\mathrm{RMN},{ }^{13} \mathrm{C}-\mathrm{RMN}$, and IR and Raman spectroscopy. The microscopic images display amorphous yellowish granulates with heterogeneous chemical surfaces. Negative ${ }^{1} \mathrm{H}-\mathrm{RMN}$ and ${ }^{13} \mathrm{C}$-RMN results allowed conclude that the sample is free of organic matter. The SEM and EDX indicate the existence of arsenic and sulfur in the sample. Orpiment $\left(\mathrm{As}_{2} \mathrm{~S}_{3}\right)$ and pararealgar $\left(\beta-\mathrm{As}_{4} \mathrm{~S}_{4}\right)$ are yellow, while realgar $\left(\alpha-\mathrm{As}_{4} \mathrm{~S}_{4}\right)$ is an orange to red mineral. All these pigments have different vibrational bands under structural analyses such as Raman or IR spectroscopy. The IR and Raman analyses confirm the presence of orpiment. 
In fact, the IR spectrum of the archaeological sample shows the characteristic orpiment bands between 250 and $400 \mathrm{~cm}^{-1}$ due to the vAs-S mode [33-39]. The Raman spectrum (Fig. 2a) obtained shows the same spectral profile than the orpiment reference sample according to a spectrum database [32]. When comparing Fig. 2a, b, the eight bands appear at the same frequencies with similar relative intensities, indicating that they are likely the same compound. There are some minor shifts being the most noticeable the one at $359 \mathrm{~cm}^{-1}$, which is actually a different band reported as a shoulder [33]. These kinds of intensity differences are often seen on anisotropic compounds such as crystals. The archaeological orpiment is an arsenic sulphide, toxic to humans [40]. Thus, it is remarkable that people of Calama, during the Formative Period, used this type of dangerous pigment as a funerary grave good. The present analysis opens the question of how this mineral was manipulated in ancient times.

\section{Diaguita pottery}

Four samples of ceramics fragments belonging to the Museum of Limarí [20] were investigated; samples display black, white, red and brown colors (Fig. 3). The tonality of these colors goes from intense to tenuous.

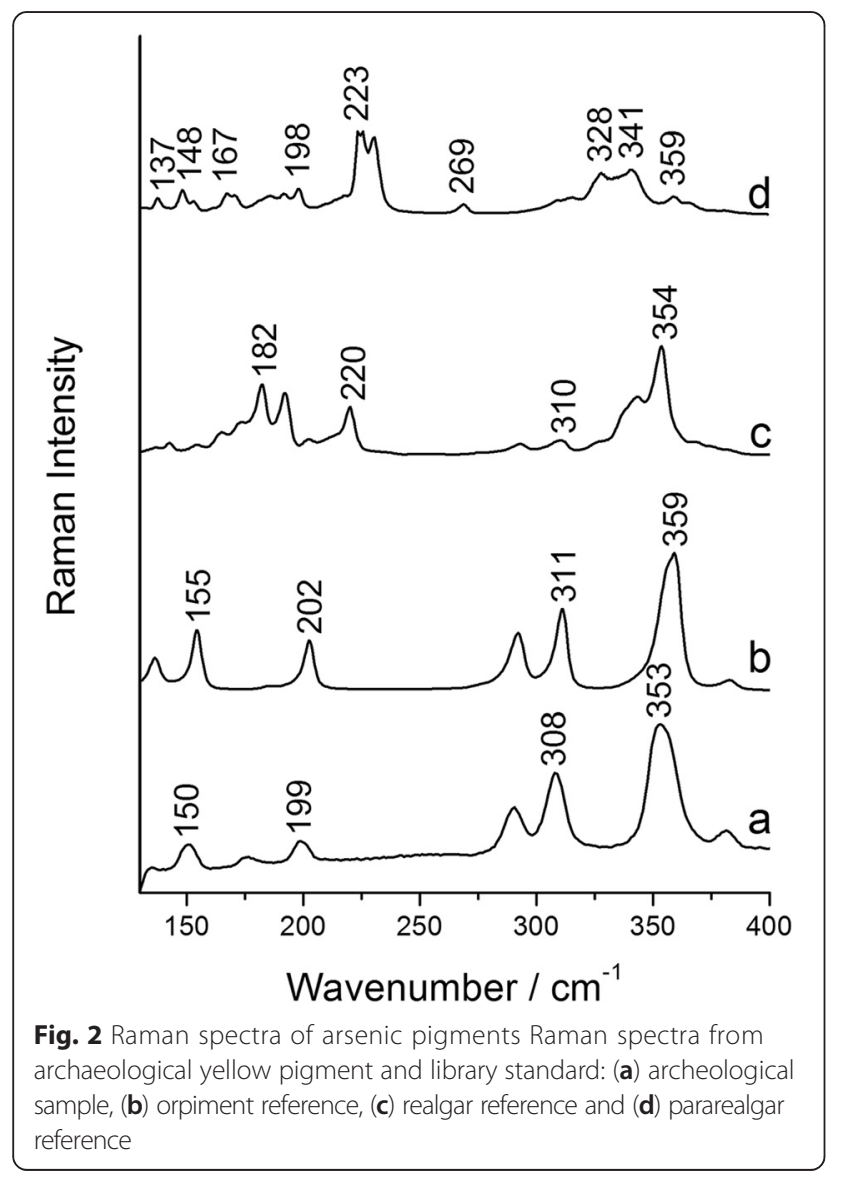

Potteries belong to the Diaguita culture, one of the distinctive original people mainly settled during the preColumbian period in the III and IV region $\left(18^{\circ}\right.$ to $31^{\circ}$ south latitude) of the Chilean territory. The Diaguita culture was mainly developed in different stages between the $9^{\text {th }}$ and $15^{\text {th }}$ century; this culture is recognized in the pre-Columbian American territory because of the plastic richness of its pottery [41]. At least three development phases in the Diaguita culture have been identified; differences arise from the complexity in the manufacturing of pottery's artifacts. The last phase is associated to the Inca rule period [42]. The present results, to our knowledge, are the first related with ceramics from the Valle del Elqui investigated through micro-Raman spectroscopy. Some chemical components identified by Raman spectroscopy in the colored areas of the pottery were crystalline silicates, namely, quartz, and pigments such as kempite and tenorite; hematite and potentially goethite were also found. The characteristic sharp band of quartz at $464 \mathrm{~cm}^{-1}$ is attributed to the $v \mathrm{Si}-\mathrm{O}$ vibration, showing some degree of shifting wavenumbers due to variations in the crystallinity of the sample. It was initially believed that the black pigment used to paint the ceramics was only a manganese salt $\left(\mathrm{Mn}_{2} \mathrm{Cl}(\mathrm{OH})_{3}\right)$ or kempite [32]. Kempite displays a band at $293 \mathrm{~cm}^{-1}$. Bands at 343, 632 and $1224 \mathrm{~cm}^{-1}$ belonging to copper oxide (II) or tenorite [32] were identified in deep black dashes of the samples [see Additional file 1]. Copper was already reported in the black pigments of PreColumbian Chilean potteries [43]. The copper content of the black color appears to be a particularity of Diaguitas; in fact, in other cultures of South America the black pigment contains iron, manganese and carbon [44-47] in their composition. The micro-Raman spectrum of sectors displaying red coloration shows characteristics bands of hematite at 223, 289, 411 and $613 \mathrm{~cm}^{-1}$. Hematite has also been found in different red tonalities from orange to brown in the decoration of Viluco and Chilean Diaguita type ceramics [48]. Additionally, in the case of the brown color it is possible to interpret this tint either as a mix of different pigments or due to only one genuine pigment (goethite). Brown areas display bands of hematite as well as bands at 1228 and $1307 \mathrm{~cm}^{-1}$ from tenorite. Also it is possible to consider this spectrum as arising from a variety of hematite like $\mathrm{FeO}(\mathrm{OH})$ (goethite) [32], which color is described, among others, as a redbrownish or ochre [see Additional file 1] [49, 50].

\section{Mural painting}

The wall painting Historia de Concepción (Fig. 4) built between 1943 and 1946, in the former Main Train Station of Concepción, Chile, is made of a mortar arrangement fixed to the wall. The total area of the painting is about $258 \mathrm{~m}^{2}$. This wall painting is another subject of 


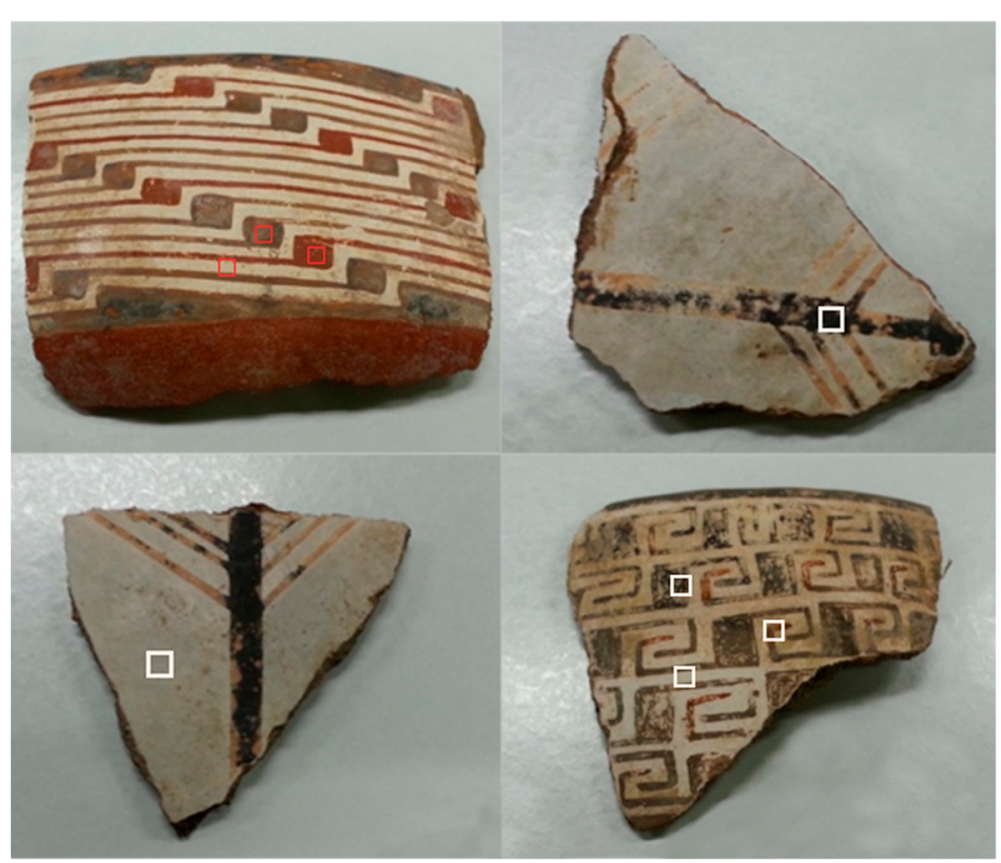

Fig. 3 Diaguita pottery fragments. Diaguita ceramic fragments. Points where micro-Raman measurements were performed are marked on a square

interest in the present work [12]. This artwork displays intense deterioration originated mainly from earthquakes and permanent environmental humidity; efflorescence and pulverization are observed in some zones. Research projects dealing with the diagnosis of the current conservation state of the wall painting considered the Raman microscopy to identify pigments and frescorelated materials. Samples were collected with a brush and scalpel from the wall painting; samples of dimensions $0.5-1 \mathrm{~mm}^{2}$ were selected according to the main colors displayed in the artwork and from zones where apparently they were altered after its creation.

The pigments found in the wall painting Historia de Concepción are mostly in agreement with those expected for a fresco [see Additional file 1], except for toluidine red and minium. Some mixtures of hematite and minium,

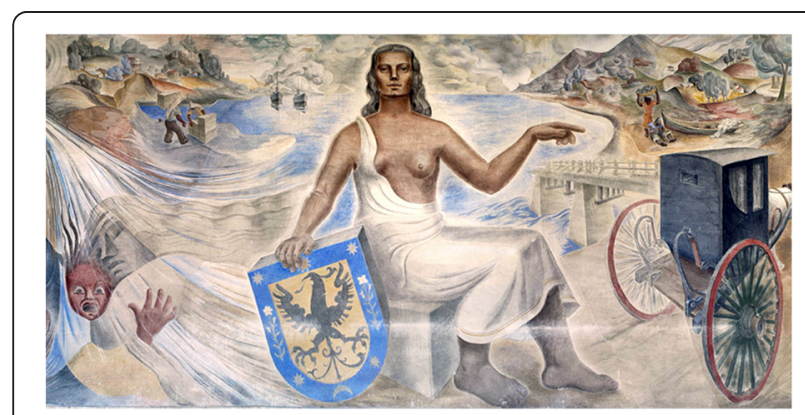

Fig. 4 Wall painting detail. Detail of the central character on the wall painting Historia de Concepción
$\mathrm{Pb}$ (II,IV) oxide were observed; they are identified from the characteristic Raman bands of hematite and the $\mathrm{vPb}(\mathrm{IV})-\mathrm{O}$ mode at $548 \mathrm{~cm}^{-1}$, and the $\mathrm{O}-\mathrm{Pb}(\mathrm{IV})$-O deformation mode at $119 \mathrm{~cm}^{-1}$. The $v \mathrm{~Pb}(\mathrm{II})-\mathrm{O}$ is ascribed to the band at $147 \mathrm{~cm}^{-1}$ [51]. The organic red pigment [52], toluidine red, displays bands at $1629,1503,1452,1402,1338,1325,1221$, 1190, 1131 1080, 844, 797, 723, 379 and $337 \mathrm{~cm}^{-1}$. Bands at 988,616 , and $453 \mathrm{~cm}^{-1}$ are ascribed to $\mathrm{BaSO}_{4}$ used as filler in this pigment [53]. Spectral information concerning mainly pigments and composition on the surface decidedly corresponds to the fresco technique and helps confirming historical data. The blue color is ultramarine blue $\left(\mathrm{Na}_{8-10} \mathrm{Al}_{6} \mathrm{Si}_{6} \mathrm{O}_{24} \mathrm{~S}_{2-4}\right)$, a matrix composed by sodium aluminosilicate salts and sulfur anions; this corresponds to the synthetic lazurite, the substitute of natural lapis lazuli. The band at $547 \mathrm{~cm}^{-1}$ is ascribed to $\mathrm{S}_{3}^{-}$; this molecular fragment defines the blue color [54]. The very low concentration of the $\mathrm{S}_{2}^{-}$anion (yellow) with a Raman band at $580 \mathrm{~cm}^{-1}$ in the blue pigments, gives rise to the green tones associated with some ultramarine pigments. The yellow color pigments with bands at 299, 387, 481 and $550 \mathrm{~cm}^{-1}$ are mainly due to goethite $\alpha-\mathrm{FeO}(\mathrm{OH})[55,56]$. The intensity of some blue and yellow zones on the wall painting and the exact coincidence with the pigments analyzed from the studio allowed to infer that at least these two colors were repainted. Samples containing the black pigment display bands at about 1595 and $1319 \mathrm{~cm}^{-1}$ certainly ascribed to amorphous carbon. This pigment is known as 
carbon black [52]; the absence of the band at $960 \mathrm{~cm}^{-1}$, of the phosphate moiety in calcium phosphate [57], suggests the vegetal origin of the coal in the fresco. The white color is due to $\mathrm{CaCO}_{3}$ (band at $1090 \mathrm{~cm}^{-1}$ ), which is the binder used in this painting technique; gypsum $\left(\mathrm{CaSO}_{4} \cdot 2 \mathrm{H}_{2} \mathrm{O}\right)$ displays a characteristic band at $1011 \mathrm{~cm}^{-1}$. The green color is due to the chromiu$\mathrm{m}$ (III) oxide $\left(\mathrm{Cr}_{2} \mathrm{O}_{3}\right)$, the main green chromophore in the mural painting, with bands at ca. 554 and $349 \mathrm{~cm}^{-1}$ $[58,59]$. The identified pollutants suggest that the strong pulverization observed in this wall painting is probably due to the successive transformation of calcite into gypsum. Large gypsum crystals detach sand from the calcite matrix. The pulverization in different degrees of the painting layer produced by this phenomenon appears on the whole surface. This suggests that sulfate impurities were probably present in the original materials used by the artist. It is probable that external pollutants are acting on some areas that appear more affected today. Pulverization continues due to the high humidity in Concepción, Chile.

\section{Painted beams}

Structural painted beams (Fig. 5) and a wall painting were recently discovered in the San Francisco church, Santiago, Chile [21]. Information dealing with the origin of these artworks that belong to the same time period, between the end of the $17^{\text {th }}$ and the $19^{\text {th }}$ century is rather inexistent. In this section we discussed the painting technique used in the beams from the identification of their materiality, in particular pigments, ground layers, supports and ultimately agglutinants. Besides microRaman spectroscopy, materials were studied by using complementary techniques as microchemistry and optical microscopy.

Five different designs painted on the beams, arranged in 2 of the 5 different rooms, and a single beam in the San Diego room of the Franciscan museum, in the architectonic complex of the San Francisco church were selected for the spectral study. The museum is installed in the ancient convent built between 1800 and 1850. Samples selected from the different beams were carefully extracted following international procedures [60]. The paint layer was analyzed separately from the wood and the supporting material. The microscopic analysis of samples of wood from the beams was carried out following Richter et al. [61].

The cross section of the painted beams of the San Francisco church indicates the existence of four different layers; from the outside the pigments, then the preparation layer, a cotton rag paper [62], and the wood. Cotton rag paper is made from cotton linters or cotton from rags as the main material source [62]; cotton was identified using optical microscopy. Microscopic observation indicated that the wood samples correspond to the conifer, genus cupressus. The Franciscan congregation in 1779 ordered cypress beams to be prepared from trees cut in La Dehesa forest, in the foothills of Santiago [63]; this agrees with the species identified, thus confirming the uniqueness of the beams. The fuchsine test was positive for the rag paper and the preparation layers, suggesting that the rag paper was imbibed with a protein component, as the binding media to apply pigments. IR bands of protein were observed at 1623 and $1553 \mathrm{~cm}^{-1}$ corresponding to the amide I and II vibrations, respectively [64]. The micro-chemical analysis of the preparation layer indicates the presence of gypsum $\left(\mathrm{CaSO}_{4} \cdot 2 \mathrm{H}_{2} \mathrm{O}\right)$. The white color from the beams containing pigment and preparation layer, is gypsum for the base layer, and calcite $\left(\mathrm{CaCO}_{3}\right)$ band at $1087 \mathrm{~cm}^{-1}$ for the pigment. The green color resulted from a mixture of orpiment and ultramarine blue. The intense Raman signal at $838 \mathrm{~cm}^{-1}$ of the yellow color is characteristic of chrome yellow [see Additional file 1] $\left(2 \mathrm{PbSO}_{4} \cdot \mathrm{PbCrO}_{4}\right.$ or $\left.\mathrm{PbCrO}_{4}\right)[65,66]$.

\section{Historical silks}

Two sets of samples were selected from the costume collection of the Museo Histórico Nacional of Chile [22]; these samples belong to a group of textiles exhibiting
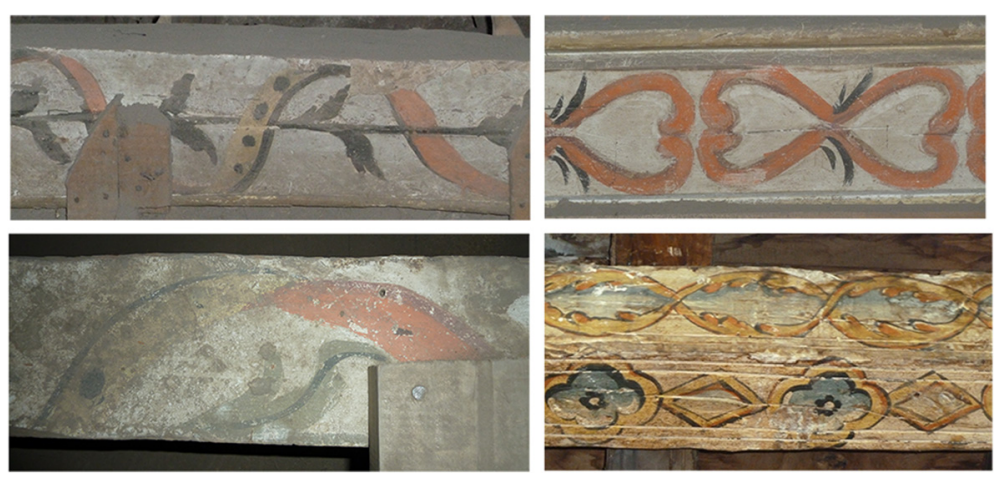

Fig. 5 Polychrome beams examples. Structural polychrome beams found in the San Francisco church in Santiago 
worrying levels of deterioration. The first group includes light color weighted silk samples highly friable; its degradation has continued over time despite being stored under controlled conditions. A second group includes samples of dark silk belonging to the same period as the light samples, but differentiated by a lesser degradation with respect to the stability of the textiles. Samples of Bombyx mori silk fibroin, and its motif peptide component (GAGAGS) were also studied by using mainly Raman and surface enhanced Raman scattering (SERS) techniques [67]. Silk degumming, weighting and dyeing processes effects on the degradation of Bombyx mori silk fibroin were investigated through the ATR-IR and Raman techniques along with SEM/EDS microscopy.

The Raman spectrum of the raw Bombyx mori silk (CS), has many similarities with the spectral profile of the peptide GAGAGS, the crystal fraction dominating the spectrum [67]. The ATR-IR spectrum of the raw silk shows two strong bands at 1617 and $1511 \mathrm{~cm}^{-1}$. The ATR-IR spectra of the degummed silks samples using the same method [68] but different $\mathrm{pH}$, temperature and time conditions DS1 (pH 10, at constant boiling temperature for $1 \mathrm{~h}$.) and DS2 $\left(\mathrm{pH} 8.5\right.$, at constant $85^{\circ} \mathrm{C}$ for $2 \mathrm{~h}$.), display the same profile except for the intensity variation of the bands at 1617, 1440 and $1403 \mathrm{~cm}^{-1}$. Relative to the spectrum of CS, the intensity of the first band decreases in the sample DS1 and displays the same relative intensity in sample DS2. In both degummed samples the band at $1063 \mathrm{~cm}^{-1}$ reduces drastically its intensity when compared with the spectrum of CS. The spectral variation of the sericin bands [69] at 1403 and $1063 \mathrm{~cm}^{-1}$ is consistent with the degumming process used. Raman spectral modifications between the CS and degummed samples were also observed. In general, no protein conformational changes can be inferred from
Raman spectral variations observed for amide I (1650$\left.1670 \mathrm{~cm}^{-1}\right)$ and amide III $\left(1230-1280 \mathrm{~cm}^{-1}\right)$ vibrations, and skeletal modes in the $900-960 \mathrm{~cm}^{-1}$ spectral region [70]. The $\mathrm{pH}$, time and temperature parameter modifications of degumming methods could produce the observed spectral changes. Thus, the degumming process exposes the single fibroin protein.

No historical information on the weighting process type used in the case of cream color lining, lining of a pink dress and a purse samples has been reported. ATRIR bands at about 969 and $995 \mathrm{~cm}^{-1}$, and 955 and $993 \mathrm{~cm}^{-1}$ are ascribed to silicate and phosphate fragments, respectively (Fig. 6). The bands of the fibroin are displayed with the same spectral profile as in the case of the isolated fibroin. The relative intensity of the amide I and II bands allows differentiating the dynamite and pink weighting processes, this is, when the intensity of the amide bands is similar to the group of bands at about $970 \mathrm{~cm}^{-1}$ it is possible to propose that the pink process was used. A strong intensity of the amide bands is characteristic of a dynamite weighting process [71]. The spectral shift of the band at $1617-1623 \mathrm{~cm}^{-1}$ gives account of the chemical effects of metal atoms on the fibroin component induced by different weighting processes in the series of the historical weighted silks as concluded by Taddei et al. [72].

On the other hand, and in order to investigate about the weighting process used in the historical samples we have prepared tannin-weighted silks from the unweighted white silk sample. Two tannin weighted samples TWS1 and TWS2 were obtained by using a first and a second charge procedure, respectively. The samples display identical ATR spectra and both similar to the un-weighted sample. The expected IR bands of the gallic acid [73] or the iron gallic complex [74] are

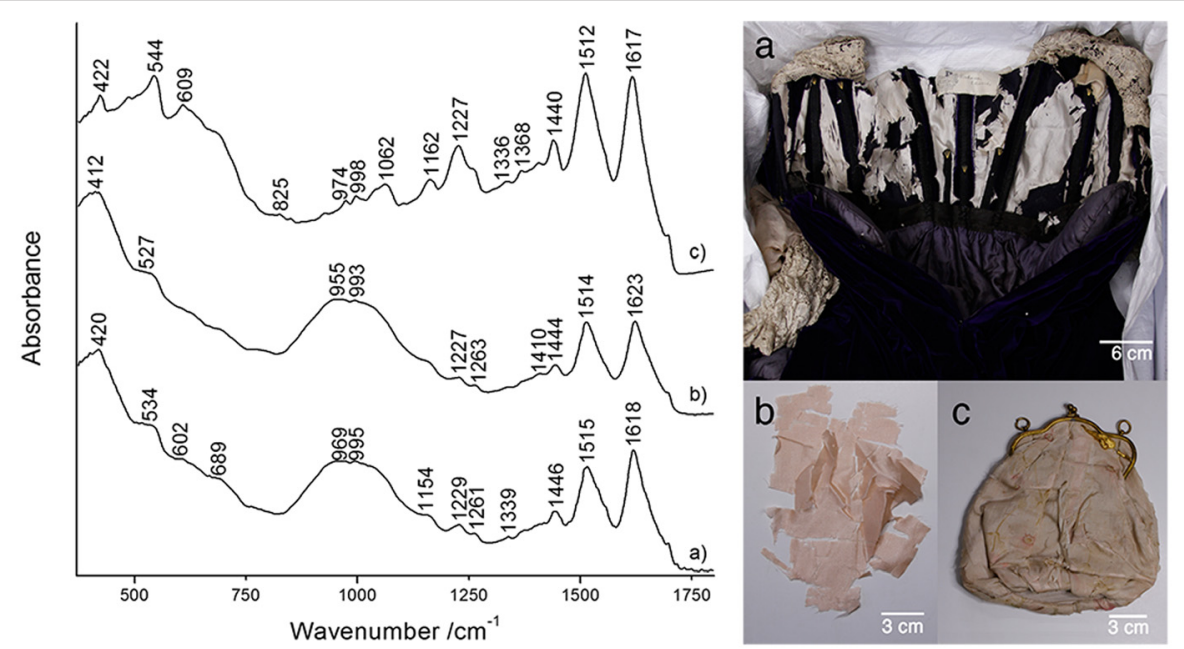

Fig. 6 ATR of historic weighted silk. ATR-IR spectra of weighted historic silk samples obtained over a diamond window: a) cream color lining, b) lining of a pink dress and $\mathbf{c}$ ) a purse 
probably masked by the fibroin bands. The Raman spectra of the samples are very similar and dominated by the iron (II)/gallic acid complex; this is also similar to the Raman spectrum of the iron gall inks. The most intense bands of the metal complex are located at 1473, 1318, $960,813,582$ and $535 \mathrm{~cm}^{-1}$, and the spectrum of the complex has the same spectral profile of that reported by Lee et al. [75]. The present Raman results are highly consistent with the fact that the tannin weighting processes does not modify the silk fibroin structure; the weighting agent dominates the Raman spectrum. On the basis of the above results we recognize the formation of the iron-gallic acid complex and thus we propose that the iron atom could act as a molecular assembler between the fibroin and the gallic moiety.

In a recent publication concerning the RB5 dyed silk we observed that the Raman signals are mainly due to the dye [41]. In the case of some historic samples of dyed silks analyzed, the ATR spectrum of one of them dated the beginning of the $20^{\text {th }}$ century, displays bands easily ascribed to silk fibroin and two intense bands at 2073 and $492 \mathrm{~cm}^{-1}$. In another sample black weft and pink warp fibers were identified. The Raman spectrum of the black warp fiber displays bands at 2166, 530 and $273 \mathrm{~cm}^{-1}$, corresponding to Prussian blue; then, the warp fiber was stained with Prussian blue. According to Hacke [76] the stannous and iron chloride solutions were used as mordant of the Napoleon blue a modification of the Prussian blue pigments. The SEM-EDS data indicate the presence of tin and iron confirming that these mordant were used in this sample. The spectral analysis of the pink warp allows identifying silk bands. In the case of the Manila mantle dated to the late nineteenth or early twentieth century showing a black to brown fading, no Raman spectra of the silk were obtained; the laser excitation probably induced the sample degradation. To avoid the degradation we used the SERS methodology and the $785 \mathrm{~nm}$ laser line for the study. The SERS signals correspond to the dye Sudan Black B following Geiman et al. [77] and the Raman data [see Additional file 1].

\section{Conclusions}

Raman results of the yellow blocks from the archaeological site Playa Miller 7 (PLM7), on the coast of Atacama Desert in northern Chile, allowed identify natrojarosite and $\mathrm{K}$-jarosite type compounds as the main components. A spectral comparison between the archaeological samples and those collected in Andean geothermal areas of Arica and Parinacota: Jurasi (JU), located at $4000 \mathrm{~m}$ above the sea level, permitted propose that this hydrothermal source was probably used as obtaining source of yellow pigment by pre-Hispanic inhabitant of the Formative Period (3700-1500 years B.P.).
Sources of pigments such as arsenic sulfides could be interesting to trace and identify their hidden dangers in ancient populations, Formative Period, of northern Chile [78]. Colorful pigments (manganese, iron) and funerary behavior have been reported for the Chinchorro Culture and for rock art in northern Chile [79]. The use of orpiment allows infer that ancient populations were familiar with several pigments that are beautiful but some dangerous to human health [80]. Future studies could focus on the sources of origin, extraction and management of this dangerous mineral.

Red, black, brown and white colors were identified in ceramic fragments from the unknown contexts of the Diaguita culture. The Raman data allowed distinguish the use of the pigments such as quartz and manganese (kempite) salts, as well as different types of oxide pigments, hematite, tenorite and possibly goethite.

The Raman microscopy was used to identify pigments and fresco-related materials from the wall painting Historia de Concepción by Gregorio de la Fuente in Concepción. Subsequent interventions were recognized when pigments were compared with those originals obtained from the artist's studio. Salt efflorescence materials were identified. The results contribute to the diagnosis of the current conservation state of the wall painting and consequently its future restoration.

Structural painted beams in the San Francisco church were analyzed by using different techniques including the micro-Raman spectroscopy. Animal protein was identified in the ground layer. The supporting material of the beams was identified as cypress wood, and a rag paper layer was used as a base for the paint layer, mainly composed by a white ground layer on which the color was then added; the yellow pigments are orpiment and chrome yellow. The green color probably arises from a mixture of orpiment, red lead, ultramarine blue and calcite.

A set of degummed and weighted silks was prepared in order to recognize the vibrational profile associated with the processes used. On this basis, the Raman and ATR-IR spectral information allowed the identification of the weighting process and also the dyes used in some of the different historic silk objects studied. The different spectra also allowed infer about the deterioration observed in the samples. The silk fibroin displays slight conformational modifications by the weighting process. The degumming process seems to have no chemical effect on the fibroin stability.

Vibrational spectroscopy are hereby shown as a versatile group of techniques, suitable to the study of the widespread materials found in the Chilean cultural heritage giving valuable information that allowed in each case to increase the knowledge about objects, contexts, etc. 
Several objects belonging to the Chilean cultural heritage have been studied using vibrational techniques besides those here exposed. No data are at present available in the form of technical reports from the associated institutions of our cooperation network. This information is important, as those institutions are reference centers for Conservation of Cultural Heritage in Chile.

\section{Methods}

\section{Raman and SERS}

Raman and SERS spectra were recorded on a Raman Renishaw Microscope System RM1000 apparatus with an electrically cooled charge-coupled device (CCD) detector, equipped with 514, 633 and $785 \mathrm{~nm}$ laser lines for excitation, coupled to a Leica microscope. The $785 \mathrm{~nm}$ laser line was the most used in the different objects since is the less energetic and thus it is less probable to induce resonance or fluorescence than with the other laser lines. The instrument was calibrated using the $520 \mathrm{~cm}^{-1}$ line of a Si wafer and the spectral scanning conditions are chosen to avoid sample degradation and photodecomposition or photo-bleaching. The chosen conditions involved the laser line used, the laser power on the samples, which is usually set in the range 1-10\% (maximum power on the sample not higher than $5 \mathrm{~mW}$ on every wavelength), spectral resolution, accumulations and time of exposure. The parameters mentioned above are usually set in each case to obtain the best spectral quality using the softer conditions possible. SERS measurements were performed by depositing a drop of the colloidal solution over the sample in a clean quartz slide and letting it dry at room temperature. The spectrum was then acquired as described above. Data are collected and analyzed using the programs WIRE 2.0 and GRAMS 8.0. Raman spectra of samples, which were impossible to be accommodated in the area of bench instrumentation, were obtained by using an i-Raman portable instrument from B\&W Tek equipped with the $785 \mathrm{~nm}$ laser line, a thermoelectrically cooled CCD detector and a $1 \mathrm{~m}$ optical fiber probe. Before each measurement a dark scan is acquired to improve the $\mathrm{S} / \mathrm{N}$ ratio. No spectral corrections (i.e. smoothing, baseline, etc.) were performed.

\section{Infrared}

The infrared spectra are measured on a FT-IR Bruker Vector 22 and on a Perkin-Elmer series 2000 apparatus both equipped with a DTGS detector. The spectral resolution was $4 \mathrm{~cm}^{-1}$ and 16 scans, spectral scanning conditions generally used, were performed. A $\mathrm{KBr}$ or polyethylene pellets are used according the spectral region scanned. FT-IR attenuated total reflectance (ATR-IR) spectra were acquired over a diamond window with a Bruker alpha FT-IR spectrometer over the range $4000-370 \mathrm{~cm}^{-1}$, accumulating 128 scans at a spectral resolution of $4 \mathrm{~cm}^{-1}$, and over a Ge ATR window on a Thermo Nicolet iZ10 apparatus.

\section{Nanoparticles synthesis and characterization}

Silver nanoparticles to be used in the SERS experiments were prepared by chemical reduction of silver nitrate with hydroxylamine [81]. The size distribution of the nanoparticles is in the range $60-150 \mathrm{~nm}$, with the most probable size around $80 \mathrm{~nm}$; the FWHM of the plasmon absorption of silver colloids is $90 \mathrm{~nm}$. The aqueous solutions utilized for the Ag-NPs formation were prepared by using deionized (18M $\Omega$ ) water. A diode array spectrophotometer Hewlett Packard 8452 A is used to scan the extinction spectra. The colloid shows an extinction spectrum showing a maximum ca. $411 \mathrm{~nm}$. A control of the colloidal solution is carried out by measuring the Raman spectrum from aggregates dried at room temperature.

\section{Scanning electron microscope measurements}

The morphological characterization of the weighted silks samples and their elemental composition were analyzed in a scanning electron microscope coupled with an energy dispersive spectroscopy device (SEM/EDS) from Electron Microscopy Ltd, England LEO 1420 variable pressure VP. Morphological observations were made using high magnified images (100X-1000X) and an electron dispersive analyzer at $10-15 \mathrm{KeV}$ accelerating voltage.

\section{Additional file}

Additional file 1: Complementary Raman spectra for the article "Vibrational Spectroscopy for the Study of Chilean Cultural Heritage".

\section{Competing interests}

The authors declare that they have no competing interests.

\section{Authors' contributions}

All authors contributed to data analyses and to finalizing the manuscript. All authors have read and approved the final version. All authors read and approved the final manuscript.

\section{Acknowledgements}

This work was financially supported by project FONDECYT 1140524. T. Aguayo thanks to CONICYT for the grant N² 21110352 .

Received: 26 November 2014 Accepted: 1 May 2015

Published online: 03 June 2015

\section{References}

1. Andrikopoulos KS, Daniilia S, Roussel B, Janssens K. In vitro validation of a mobile Raman-XRF micro-analytical instrument's capabilities on the diagnosis of Byzantine icons. J Raman Spectrosc. 2006;37:1026.

2. Castro K, Pessanha S, Proietti N, Princi E, Capitani D, Carvalho ML, et al. Noninvasive and nondestructive NMR. Raman and XRF analysis of a Blaeu coloured map from the seventeenth century Anal Bioanal Chem. 2008;391:433.

3. Chaplin TD, Clark RJH, Martinón-Torres M. A combined Raman microscopy, XRF and SEM-EDX study of three valuable objects - A large painted leather 
screen and two illuminated title pages in 17th century books of ordinances of the Worshipful Company of Barbers. London J Mol Struct. 2010;976:350.

4. Rosi F, Manuali V, Grygar T, Bezdicka P, Brunetti BG, Sgamellotti A, et al. Raman scattering features of lead pyroantimonate compounds: implication for the non-invasive identification of yellow pigments on ancient ceramics. Part II. In situ characterisation of Renaissance plates by portable micro-Raman and XRF studies. J Raman Spectrosc. 2011:42:407.

5. Burgio L, Clark RJH, Muralha VSF, Stanley T. Pigment analysis by Raman microscopy of the non-figurative illumination in 16th- to 18th-century Islamic manuscripts. J Raman Spectrosc. 2008:39:1482.

6. Bellot-Gurlet L, Pagès-Camagna S, Coupry C. Raman spectroscopy in art and archaeology. J Raman Spectrosc. 2006;37:962.

7. Bersani D, Lottici PP, Vignali F, Zanichelli G. A study of medieval illuminated manuscripts by means of portable Raman equipments. J Raman Spectrosc. 2006;37:1012.

8. Ciliberto E, Spoto G. Modern analytical methods in art and archaeology. New York: Wiley; 2000

9. Clark RJH. The scientific investigation of artwork and archaeological artefacts: Raman microscopy as a structural, analytical and forensic tool. Appl Phys A. 2007;89:833.

10. Smith GD, Clark RJH. Raman microscopy in archaeological science. J Archaeol Sci. 2004;31:1137.

11. Vandenabeele P, Edwards HGM, Moens L. A decade of Raman spectroscopy in art and archaeology. Chem Rev. 2007;107:675.

12. Aguayo T, Clavijo E, Eisner F, Ossa-Izquierdo C, CamposVallette MM. Raman spectroscopy in the diagnosis of the wall painting History of Concepción. Chile J Raman Spectrosc. 2011;42:2143.

13. Casanova-González E, García-Bucio A, Ruvalcaba-Sil JL, Santos-Vásquez V, Esquivel B, Falcón T, et al. Surface-enhanced Raman spectroscopy spectra of Mexican dyestuffs. J Raman Spectrosc. 2012;43:1551.

14. Casanova-González E, García-Bucio A, Ruvalcaba-Sil JL, Santos-Vásquez V, Esquivel B, Roldán ML, et al. Silver Nanoparticles for SERS Identification of Dyes. In: MRS Online Proceedings Library. 2012. p. 263.

15. Lahlil S, Lebon M, Beck L, Rousselière H, Vignaud $C$, Reiche I, et al. The first in situ micro-Raman spectroscopic analysis of prehistoric cave art of Rouffignac St-Cernin. France J Raman Spectrosc. 2012;43:1637.

16. David AR, Edwards HGM, Farwell DW, De Faria DLA. Raman spectroscopic analysis of ancient Egyptian pigments. Archaeometry. 2001:43:461.

17. Tomasini E, Siracusano G, Maier MS. Spectroscopic, morphological and chemical characterization of historic pigments based on carbon. Paths for the identification of an artistic pigment Microchem J. 2012;102:28.

18. Sepúlveda M, Gutiérrez S, Campos-Vallette MM, Clavijo E, Walter P, Cárcamo JJ. Raman Spectroscopy and X-Ray Fluorescence in Molecular Analysis of Yellow Blocks From the Archaeological site Playa Miller 7 (Northern Chile). J Chilean Chem Soc. 2013:58:1836.

19. Ogalde JP, Salas C, Lara N, Leyton P, Paipa C, Campos-Vallette MM, et al. Multi-instrumental Identification of Orpiment in Archaeological Mortuary Contexts. J Chilean Chem Soc. in press.

20. Osorio F, Díaz Fleming G, Martínez U, Campos-Vallette MM, Clavijo E, Aliaga $A E$, et al. Micro-Raman spectroscopy of decorated pottery of the Diaguita culture from IV Region, Chile $\left(9^{\text {th }}-15^{\text {th }}\right.$ century AD). J Chilean Chem Soc. 2014;59:2248.

21. Araya C, Jaque J, Naranjo N, Icaza M, Clavijo E, Aquayo T, et al. Raman Characterization of Pigments in Painted Beams and a Wall Painting Discovered in the San Francisco Church in Santiago. Chile Spectrosc Lett. 2014;47:177.

22. Aguayo T, Araya C, Icaza M, Campos-Vallette MM. A Vibrational Approach for the Study of Historical Weighted and Dyed Silks. J Mol Struct. 2014;1075:471

23. Sepúlveda M, Rousselière $H$, Van Elslande $E_{1}$ Cárcamo JJ, Walter $P$. Caracterización de bloques amarillos del sitio Playa Miller 7 (costa norte de Chile). In: Vázquez C, Palacios O, Ciarlo N, editors. Patrimonio cultural: la gestión, el arte, la arqueología y las ciencias exactas aplicadas. Buenos Aires: CNEA; 2013. p. 263-70.

24. Rial $\mathrm{G}$, Barbosa C. Análisis mineralógico por difracción de rayos $X$ de muestras de pinturas del sitio Inca Cueva 4 (Departamento Humahuaca, Provincia de Jujuy). Cuadernos del Instituto Nacional de Antropología. 1983;10:307.

25. Boschin MT, Maier MS, Massaferro GI. Une lecture pluridisciplinaire des analyses chimiques et minéralogiques de peintures rupestres de la Patagonie Argentine. L'Anthropologie. 2011;115:360.
26. Frost RL, Wills RA, Weier ML, Martens W, Mills S. A Raman spectroscopic study of selected natural jarosites. Spectrochim Acta Pt A Mol Biomol Spectrosc. 2006;36:1.

27. Chio CH, Sharma SK, Muenow DW. Micro-Raman studies of hydrous ferrous sulfates and jarosites. Spectrochim Acta Pt A Mol Biomol Spectrosc. 2005;61:2428.

28. Desborough GA, Smith KS, Lowers HA, Swayze GA, Hammarstrom JM, Diehl $\mathrm{SF}$, et al. Mineralogical and chemical characteristics of somenatural jarosites. Geochim Cosmochim Acta. 2010;74:1041.

29. Frost RL, Wills RA, Weier ML, Martens W, Mills S. Comparison of the Raman spectra of natural and synthetic K- and Na-jarosites at 298 and 77K. J Raman Spectrosc. 2005;36:435.

30. Sasaki K, Tanaike O, Konno H. Distinction of jarosite-group compounds by Raman spectroscopy. Can Mineral. 1998:36:1225.

31. Lin V, Colthup NB. Fateley WG. Grasselli JG: The handbook of infrared and Raman characteristic frequencies of organic molecules. Academic Press, Boston; 1991.

32. The RRUFF Project [http://rruff.info]

33. Forneris $\mathrm{R}$. The infrared and Raman spectra of realgar and orpiment. Am Mineralogist. 1969;54:1062.

34. Kendix E. Transmission and Reflection (ATR) Far-Infrared Spectroscopy Applied in the Analysis of Cultural Heritage Materials, PhD Thesis. Bologna: Università di Bologna; 2009.

35. Kendix E, Prati S, Joseph E, Sciutto G, Šazzeo RM. ATR and transmission analysis of pigments by means of far infrared spectroscopy. Anal Bioanal Chem. 2009;394:1023.

36. Itoh ST, Fujiwara T. Vibrational properties of $\mathrm{As}_{2} \mathrm{~S}_{3}$ glass. J Non-Cryst Solids. 1982;51:175

37. Trajkovskal M, Šoptrajanov B, Jovanovski G, Stafilov T. Vibrational spectra of some sulfide minerals from alšar. J Mol Struct. 1992;267:191.

38. Colomban P, Tournie A, Bellot-Gurlet L. Raman identification of glassy silicates used in ceramics, glass and jewellery: a tentative differentiation guide. J Raman Spectrosc. 2006;37:841.

39. Soong R, Farmer VC. The Identification of Sulphide Minerals by Infra-Red Spectroscopy. Mineral Mag. 1978;42:277.

40. Buchanan JA, Eberhardt A, Tebb Z, Heard K, Wendlandt RF, Kosnett M. Massive Human Ingestion of Orpiment (Arsenic Trisulfide). J Emerg Med. 2013:44:367.

41. Ampuero Brito G. La cultura Diaguita. Santiago: Departamento de Extensión Cultural del Ministerio de Educación; 1978.

42. Ampuero Brito G. Diaguitas, Pueblos del Norte Verde. Santiago: Museo de Arte Precolombino; 1986.

43. Dinator M, Morales J. Characterization of colour pigments in pre-Columbian Chilean potteries by PIXE elemental analysis. J Radioanal Nucl Ch. 1990;140:133.

44. De la Fuente GA, Pérez Martínez JM. Estudiando pinturas en cerámicas arqueológicas "Aguada Portezuelo" (ca. 600-900 AD) del Noroeste Argentino: nuevos aportes a través de una aproximación arqueométrica por microespectroscopía de Raman (MSR). Intersecciones antropol. 2008;9:173.

45. Cremonte MB, Baldini M, Botto IL. Pastas y colores: Un camino a conocimiento del estilo Portezuelo de Aguada. Intersecciones antropol. 2003:4:3.

46. Van der Weer J, Smith GD, Firth S, Clark RJH. Identification of black pigments on prehistoric Southwest American potsherds by infrared and Raman microscopy. J Arch Sci. 2004;31:1429.

47. De la Fuente GA, Kristcautzky N, Toselli G, Riveros A. Petrología cerámica comparativa y análisis composicional de las pinturas por MEB-EDS de estilo Aguada Portezuelo (ca. 600-900 DC) en el Valle de Catamarca (Noroeste Argentino). Estud Atacam. 2005;30:61.

48. Tuñón López JA, Sánchez Vizcaíno A, Chiavazza H, Montejo Gámez M. Los colores de la cerámica Viluco y Diaguita Chilena: determinación de los pigmentos utilizados en la decoración cerámica indígena del norte de Mendoza (Argentina) mediante Microespectroscopía Raman y microfluorescencia de energía dispersiva de rayos X. Estudos Arqueológicos de Oeiras. 2012;19:193.

49. Hanesch M. Raman spectroscopy of iron oxides and (oxy)hydroxides at low laser power and possible applications in environmental magnetic studies. Geophys J Int. 2009;177:941.

50. De Faria DLA, Silva SV, De Oliveira MT. Raman microspectroscopy of some iron oxides and oxyhydroxides. J Raman Spectrosc. 1997;28:873. 
51. Bussotti L, Giuntini L, Carboncini M, Mandú P, Castellucci E. Identification of Pigments in a fourteenth-century miniature by combined micro-Raman and PIXE spectroscopic techniques. Stud Conserv. 1997;42:83.

52. Eastaugh N, Walsh V, Chaplin T, Siddall R. Pigment Compendium: A Dictionary of Historical Pigments. Oxford: Elsevier Butterworth-Heinemann; 2004

53. Burgio L, Clark RJH. Library of FT-Raman spectra of pigments, minerals, pigment media and varnishes, and supplement to existing library of Raman spectra of pigments with visible excitation. Spectrochim Acta Pt A Mol Biomol Spectrosc. 2001;57:1491.

54. Ledè B, Demortier A, Gobeltz-Hautecúur N, Lelieur J, Picquenard E, Duhayon E. Observation of the $v_{3}$ Raman band of $S_{3}^{-}$inserted into sodalite cages. J Raman Spectrosc. 2007;38:1461.

55. Correia AM, Clark RJH, Ribeiro MI, Duarte ML. Pigment study by Raman microscopy of 23 paintings by the Portuguese artist Henrique Pousao (1859-1884). J Raman Spectrosc. 2007;38:1390.

56. Legodi MA, De Waal D. The preparation of magnetite, goethite, hematite and maghemite of pigment quality from mill scale iron waste. Dyes Pigments. 2007;74:161

57. Sauer G, Zunic W, Durig J, Withier R. Fourier transform Raman spectroscopy of synthetic and biological calcium phosphates. Calcif Tissue Int. 1994:54:414.

58. Zuo J, Xu C, Hou B, Wang C, Xie Y, Qian Y. Raman Spectra of Nanophase $\mathrm{Cr}_{2} \mathrm{O}_{3}$. J Raman Spectrosc. 1996:27:921

59. Sousa PM, Silvestre AJ, Popovici N, Conde O. Morphological and structural characterization of $\mathrm{CrO}_{2} / \mathrm{Cr}_{2} \mathrm{O}_{3}$ films grown by Laser-CVD. Appl Surf SCi. 2005;247:423.

60. Gómez ML. La Restauración: Examen científico aplicado a la conservación de obras de arte. Madrid: Cátedra; 1998.

61. Richter HG, Grosser D, Heinz I, Gasson PE. IAWA List of Microscopic Features for Softwood Identification. IAWA J. 2004;25:1.

62. Crespo C, Viñas $V$. The preservation and restoration of paper records and books: a ramp study with guidelines. Paris: Unesco; 1985.

63. Rovegno J: La casa de Fray Pedro de Bardeci. El Convento de San Francisco, Santiago de Chile. Ensayo cronológico 1554-2004. Santiago, Orden Franciscana de Chile. Ediciones Alameda, Santiago; 2009.

64. Centeno SA, Guzman MI, Yamazakikleps A, Della Védova CO. Characterization by FTIR of the Effect of Lead White on Some Properties of Proteinaceous Binding Media. JAIC. 2004;43:139.

65. Castro K, Pérez-Alonso M, Rodríguez-Laso M, Fernández L, Madariaga J. On-line FT-Raman and dispersive Raman spectra database of artists' materials (e-VISART database). Anal Bioanal Chem. 2005;382:248.

66. Bell IM, Clark RJH, Gibbs P. Raman spectroscopic library of natural and synthetic pigments (pre- approximately 1850 AD). Spectrochim Acta Pt A Mol Biomol Spectrosc. 1997:53A:2159.

67. Aguayo T, Garrido C, Clavijo RE, Gómez-Jeria JS, Araya C, Icaza M, et al. Raman and surface enhanced Raman scattering of a black dyed silk. J Raman Spectrosc. 2013;44:1238.

68. Choudhury AKR: Textile Preparation Dyeing. Science Publishers, New Hampshire; 2006:237

69. Monti P, Freddi G, Arosio C, Tsukada M, Arai T, Taddei P. Vibrational spectroscopic study of sulphated silk proteins. J Mol Struct. 2007:834-836:202.

70. Frushour BG, Koenig JL. Raman Spectroscopy of Proteins. In: Clark RJH, Hester RE, editors. Advances in Infrared and Raman Spectroscopy Vol. 1. London: Heyden; 1975. p. 35

71. Garside $P$, Wyeth $P$, Zhang X. Understanding the ageing behaviour of nineteenth and twentieth century tin-weighted silks. J Institute Conservation. 2010:33:179.

72. Taddei P, Monti P, Freddi G, Arai T, Tsukada M. IR study on the binding mode of metal cations to chemically modified Bombyx mori and Tussah silk fibres. J Mol Struct. 2003;651:433.

73. Jankovic IA, Saponjic ZV, Dzunuzovic ES, Nedeljkovic JM. New Hybrid Properties of $\mathrm{TiO}_{2}$ Nanoparticles Surface Modified With Catecholate Type Ligands. Nanoscale Res Lett. 2010;5:81.

74. Senvaitiene J, Beganskiene A, Kareiva A. Spectroscopic evaluation and characterization of different historical writing inks. Vib Spectrosc. 2005;37:61.

75. Lee AS, Mahon PJ, Creagh DC. Raman analysis of iron gall inks on parchment. Vib Spectrosc. 2006;41:170

76. Hacke M. Weighted silk: history, analysis and conservation. Rev Conserv. 2008;9:3.
77. Geiman I, Leona M, Lombardi JR. Application of raman spectroscopy and surface-enhanced raman scattering to the analysis of synthetic dyes found in ballpoint pen inks. J Forensic Sci. 2009:54:947.

78. Ambers J. Raman analysis of pigments from the Egyptian Old Kingdom. J Raman Spectrosc. 2004;35:768.

79. Van Hoesen J, Arriaza B. Characterizing the micromorphology of sediments associated with chinchorro mummification in Arica. Chile usin SEM and EDS Archaeometry. 2011;53:986.

80. Arriaza BT, Cornejo L, Lienqueo H, Standen VG, Santoro CM, Guerra N, et al. Caracterización química y mineralógica de los materiales grises de los cuerpos Chinchorro modelados. Chungará. 2012;44:177.

81. Leopold N, Lendl BJ. A new method for fast preparation of highly Surface-Enhanced Raman Scattering (SERS) active silver colloids at room temperature by reduction of silver nitrate with hydroxylamine hydrochloride. J Phys Chem B. 2003;107:5723.

\section{Publish with ChemistryCentral and every scientist can read your work free of charge \\ "Open access provides opportunities to our colleagues in other parts of the globe, by allowing anyone to view the content free of charge." \\ W. Jeffery Hurst, The Hershey Company.}

- available free of charge to the entire scientific community

- peer reviewed and published immediately upon acceptance

- cited in PubMed and archived on PubMed Central

- yours - you keep the copyright

Submit your manuscript here:

http://www.chemistrycentral.com/manuscript/
()

ChemistryCentral 